\title{
A boninitic dyke in the eastern Sukkertoppen region: geochemistry of the boninitic-noritic dyke swarm of southern West Greenland
}

\author{
R. P. Hall and D. J. Hughes
}

Large early Proterozoic (c. $2100 \mathrm{Ma}$ ) basic dykes occur throughout the Archaean craton of southern West Greenland (Allaart, 1975, 1982; Bridgwater et al., 1985; Kalsbeek \& Taylor, 1985) and have become known as the MD (meta-dolerite) dykes (Bridgwater et al., 1976). Four generations (MD1, MD2, MD3a and MD3b) can be distinghushed by their mutually discordant relationships and their progressively evolved geochemistry along an apparently common tholeiitic trend (Rivalenti, 1975; Hall et al., 1985). However, the earliest generation comprises two distinct lithological types, one noritic and the other doleritic. Noritic dykes predominate in the eastern Sukkertoppen region (cf. Garde et al., 1983), while dolerite dykes become increasingly abundant towards the south. A few N-S trending noritic dykes extend southwards through the eastern Godthåbsfjord and Fiskenæsset regions and similar dykes occur rarely in the Frederikshåb region (Andrews, 1973, personal communication, 1985). Textural and geochemical evidence presented here from a quenched variety of the norite dykes demonstrates that these dykes crystallized from magmas with strong boninitic affinities, as has also been suggested on geochemical grounds for other dykes from the same swarm by Bridgwater et al. (1985), and that they are not genetically related to the dolerites of the tholeiitic MD swarm. In view of this evidence, and since these noritic dykes are neither metamorphosed nor dolerites, it is suggested that they should no longer be considered to be part of the MD dyke swarm, but that they warrant a new stratigraphic name.

\section{Petrography}

Most of the noritic dykes are easily distinguished petrographically by their apparently heteradcumulus texture, comprising abundant orthopyroxene (bronzite) and, to a lesser extent, olivine primocrysts enclosed by plagioclase oikocrysts with clinopyroxene occurring in varying amounts and with various early and late-stage textures (fig. 1) (Hall et al., 1985). The orthopyroxene is nucleated on olivine in some cases and both of these phases are occasionally nucleated on chromite microphenocrysts. The noritic dykes from throughout the Archaean craton share this characteristic mineralogy and texture. However, the abundant noritic dykes in the eastern Sukkertoppen region comprise a suite which also includes a partially quenched variety (fig. 2) and an evolved, granophyric variety (fig. 3).

The quenched dyke comprises a high-temperature assemblage of small $(c .1 \mathrm{~mm})$ primocrysts of olivine $\left(\mathrm{Fo}_{89-73}\right)$, orthopyroxene $\left(\mathrm{En}_{8473}\right)$ and distinctive elongate $\mathrm{Mg}$-rich pigeonite $\left(\mathrm{Wo}_{6-11} \mathrm{En}_{80-74} \mathrm{Fs}_{15}\right)$ which is typically mantled by augite $\left(\mathrm{Wo}_{33-37} \mathrm{En}_{54-49} \mathrm{Fs}_{11}\right)$, preserved within a microcrystalline quenched groundmass consisting of a wide range of more Fe-rich clinopyroxenes $\left(\mathrm{Wo}_{14} \mathrm{En}_{64} \mathrm{Fs}_{22}-\mathrm{Wo}_{31} \mathrm{En}_{41} \mathrm{Fs}_{28}\right)$, titaniferous magnetite, quartz and dendritic plagioclase $\left(c . \mathrm{An}_{55}\right)$. The granophyric dykes are medium-grained augite-norites in which zoned plagioclase $\left(\mathrm{An}_{64-36}\right)$, orthopyroxene $\left(\mathrm{En}_{84-65}\right)$ and complex clinopyroxenes comprising intergrown augite $\left(\mathrm{Wo}_{35} \mathrm{En}_{50-34} \mathrm{Fs}_{15-31}\right)$ and intermediate pigeonite $\left(\mathrm{Wo}_{12} \mathrm{En}_{54-42} \mathrm{Fs}_{32-46}\right)$ are in- 


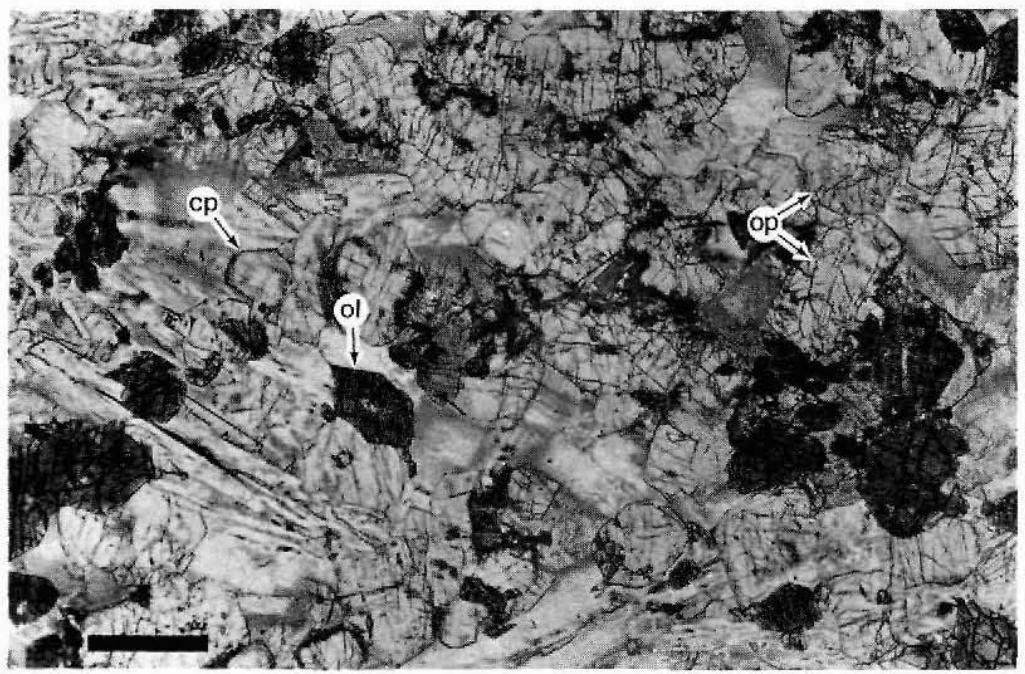

Fig. 1. Typical heteradcumulus-textured norite (GGU 277432) comprising mainly orthopyroxene (op), olivine $(\mathrm{ol})$ and some clinopyroxene $(\mathrm{cp})$ primocrysts enclosed by plagioclase oikocrysts with interstitial clinopyroxene. Scale bar represents $1 \mathrm{~mm}$.

corporated in subsequent granophyric intergrowths of alkali feldspar and quartz (fig. 3). They occur as an en echelon set trending approximately $020^{\circ}$, the southern extension of which constitutes the 'Aornit' dyke described by Berthelsen \& Bridgwater (1960).

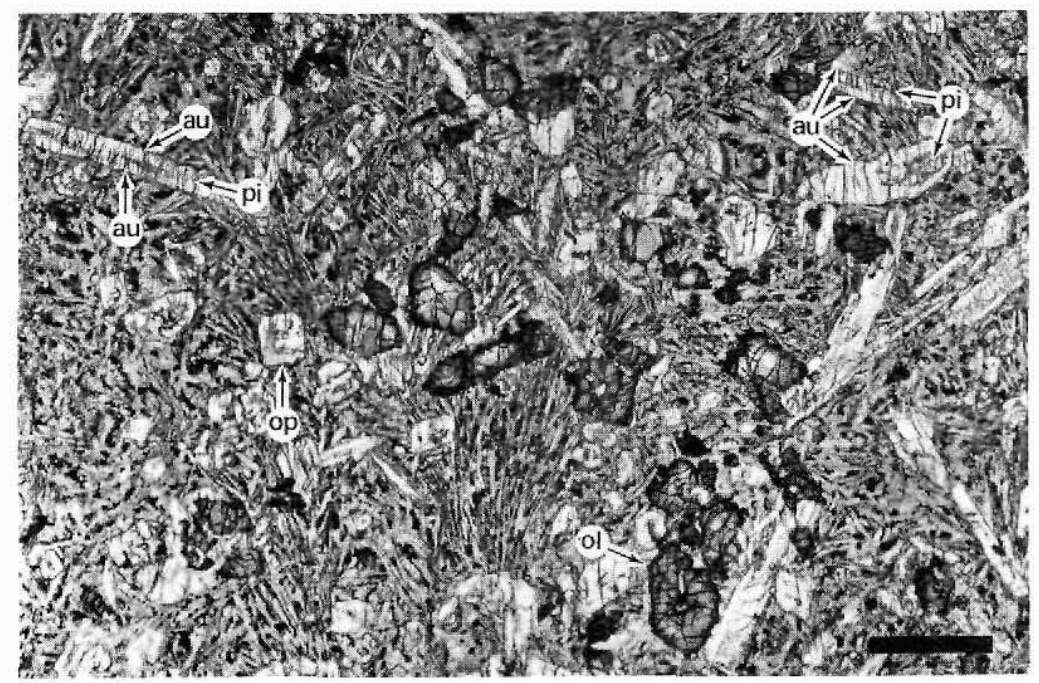

Fig. 2. Boninitic dyke (GGU 290511) comprising orthopyroxene (op), olivine (ol) and Mg-rich pigeonite (pi) mantled by augite $(\mathrm{au})$, in a quenched variable clinopyroxene + dendritic plagioclase + titaniferous magnetite $(+$ quartz) groundmass. Scale bar represents $1 \mathrm{~mm}$. 


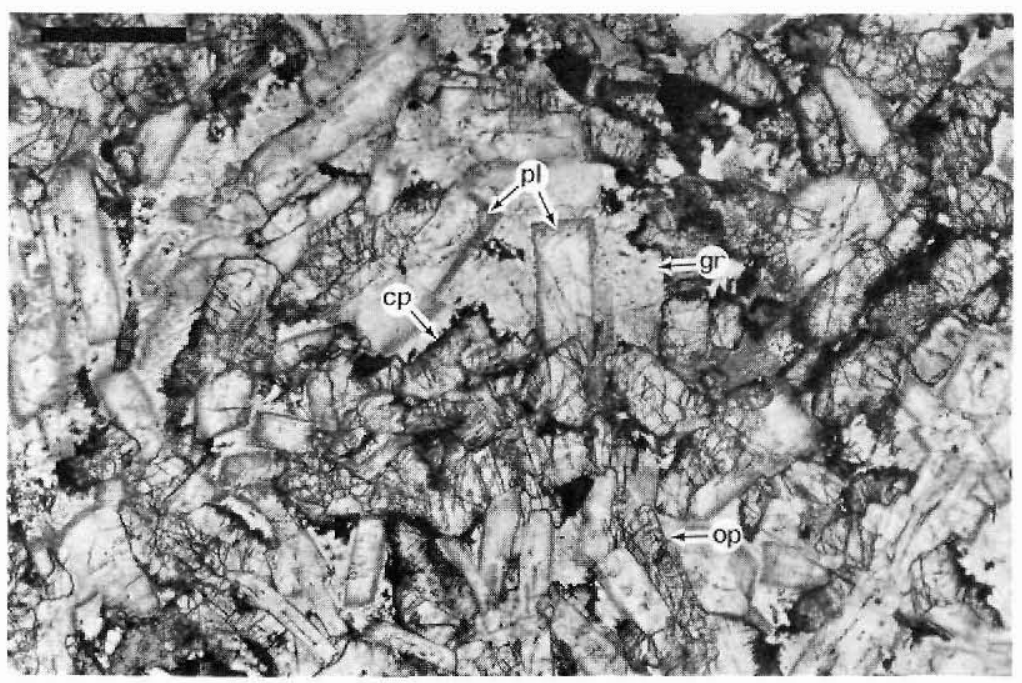

Fig. 3. Granophyric augite-norite (GGU 290506) comprising zoned orthopyroxene (op), pigeonite (pi), augite (au) and plagioclase (pl) with an interstitial granophyric quartz + alkali feldspar matrix ( $\mathrm{gr}$ ). Scale bar represents $1 \mathrm{~mm}$.

The mineralogy and textures of these three types of noritic dykes clearly distinguish them from the dolerites of the MD dyke swarm, which are nearly all composed of plagioclase and clinopyroxene with ophitic or sub-ophitic textures (Hall et al., 1985).

\section{Geochemistry}

The major and trace element geochemistry of twenty-two noritic dyke samples, collected by the authors, has been determined by X-ray fluorescence analysis at Portsmouth Polytechnic. FeO contents were determined by titration. Most of the samples were taken from dykes in the eastern Sukkertoppen region. Three samples are from different dykes on Ivisârtoq in the inner Godthăbsfjord area (Hall, 1981) (Table 1, anal. 1), one is from the Kangāngûp tasia area, north-east of Fiskenæsset (Hall, 1977) (Table 1, anal. 2) and one is from an E-W trending dyke from the south side of Evighedsfjord, to the north of Sukkertoppen.

The geochemistry of the noritic dykes is very distinctive. The bulk of the samples have high $\mathrm{MgO}(14-18 \%$; ionic $\mathrm{Mg} /(\mathrm{Mg}+\mathrm{Fe})=0.7-0.8), \mathrm{Cr}(1500-2500 \mathrm{ppm})$ and $\mathrm{Ni}(400-1000$ ppm) and low $\mathrm{Ca}, \mathrm{Al}, \mathrm{Fe}$ and $\mathrm{Ti}$ contents (fig. 4). They are unusual in that they also have relatively high $\mathrm{SiO}_{2}(49-53 \%)$ and large ion lithophile element abundances for rocks with such $\mathrm{Mg}$-rich compositions. $\mathrm{K}_{2} \mathrm{O}, \mathrm{Na}_{2} \mathrm{O}, \mathrm{Rb}, \mathrm{Sr}$ and $\mathrm{Ba}$ concentrations range from $0.5-$ $1.2 \%, 1.3-2.2 \%, 6-22 \mathrm{ppm}, 150-270 \mathrm{ppm}$ and $160-400 \mathrm{ppm}$, respectively.

The chemical composition of these rocks has been attributed mainly to the influence of crystal (orthopyroxene and olivine) accumulation (Hall et al., 1985). However, the very close similarity between the geochemistry of the quenched dyke (Table 1, anal. 3) and the more common apparently heteradcumulus-textured variety from both the same area (Table 1, anal. 5) and the Godthăbsfjord and Fiskenæsset regions strongly indicates that the geo- 
Table 1. Geochemistry of typical noritic dykes

\begin{tabular}{|c|c|c|c|c|c|}
\hline & 1 & 2 & 3 & 4 & 5 \\
\hline GGU No. & 200841 & 156023 & 290511 & 290506 & 277432 \\
\hline Locality & $\begin{array}{l}64^{\circ} 50^{\prime} \mathrm{N} \\
49^{\circ} 50^{\prime} \mathrm{W}\end{array}$ & $\begin{array}{l}63^{\circ} 26^{\prime} \mathrm{N} \\
49^{\circ} 53^{\prime} \mathrm{W}\end{array}$ & $\begin{array}{l}65^{\circ} 19^{\prime} \mathrm{N} \\
51^{\circ} 07^{\prime} \mathrm{W}\end{array}$ & $\begin{array}{l}65^{\circ} 19^{\prime} \mathrm{N} \\
51^{\circ} 10^{\prime} \mathrm{W}\end{array}$ & $\begin{array}{l}65^{\circ} 29^{\prime} \mathrm{N} \\
50^{\circ} 53^{\prime} \mathrm{W}\end{array}$ \\
\hline \multicolumn{6}{|l|}{$w t \%$} \\
\hline $\mathrm{SiO}_{2}$ & 51.04 & 51.29 & 49.50 & 56.00 & 48.77 \\
\hline $\mathrm{TiO}_{2}^{2}$ & 0.46 & 0.74 & 0.53 & 0.50 & 0.56 \\
\hline $\mathrm{Al}_{2} \mathrm{O}_{3}$ & 12.59 & 11.61 & 12.49 & 15.95 & 11.73 \\
\hline $\mathrm{Fe}_{2} \mathrm{O}_{3}$ & 1.95 & 2.19 & 1.53 & 1.19 & 1.52 \\
\hline $\mathrm{FeO}$ & 7.42 & 8.30 & 8.29 & 6.77 & 8.48 \\
\hline $\mathrm{MnO}$ & 0.18 & 0.18 & 0.18 & 0.13 & 0.19 \\
\hline $\mathrm{MgO}$ & 15.51 & 13.94 & 16.01 & 5.67 & 17.02 \\
\hline $\mathrm{CaO}$ & 7.95 & 7.49 & 7.77 & 8.59 & 7.79 \\
\hline $\mathrm{Na}_{2} \mathrm{O}$ & 1.49 & 1.96 & 2.00 & 3.25 & 2.07 \\
\hline $\mathrm{K}_{2} \mathrm{O}$ & 0.55 & 1.15 & 0.60 & 1.07 & 0.73 \\
\hline \multirow[t]{2}{*}{$\mathrm{P}_{2}^{2} \mathrm{O}_{5}$} & 0.17 & 0.23 & 0.17 & 0.15 & 0.18 \\
\hline & $\overline{99.18}$ & $\overline{99.08}$ & 99.07 & $\overline{99.24}$ & $\overline{99.04}$ \\
\hline \multicolumn{6}{|l|}{ ppm } \\
\hline $\mathrm{Cr}$ & 1914 & 1555 & 1811 & 212 & 1982 \\
\hline $\mathrm{Ni}$ & 546 & 578 & 718 & 71 & 900 \\
\hline $\mathbf{R b}$ & 9 & 26 & 6 & 18 & 9 \\
\hline $\mathrm{Sr}$ & 169 & 232 & 194 & 315 & 207 \\
\hline $\mathbf{Y}$ & 9 & 13 & 10 & 12 & 9 \\
\hline $\mathrm{Zr}$ & 50 & 100 & 55 & 80 & 62 \\
\hline $\mathbf{B a}$ & 182 & 397 & 212 & 377 & 233 \\
\hline $\mathbf{L a}$ & 12 & 19 & 11 & 14 & 15 \\
\hline \multicolumn{6}{|c|}{ CIPW norms } \\
\hline $\mathrm{Q}$ & - & - & - & 5.23 & - \\
\hline or & 3.28 & 6.86 & 3.58 & 6.37 & 4.36 \\
\hline$a b$ & 12.71 & 16.74 & 17.08 & 27.46 & 17.69 \\
\hline an & 26.26 & 19.67 & 23.55 & 26.11 & 20.76 \\
\hline $\mathrm{di}$ & 9.90 & 13.11 & 11.42 & 13.01 & 13.67 \\
\hline hy & 39.03 & 30.93 & 21.31 & 18.79 & 13.48 \\
\hline ol & 4.70 & 7.55 & 19.42 & - & 26.32 \\
\hline mt & 2.85 & 3.21 & 2.24 & 1.74 & 2.23 \\
\hline il & 0.88 & 1.42 & 1.02 & 0.96 & 1.07 \\
\hline ap & 0.40 & 0.54 & 0.40 & 0.35 & 0.42 \\
\hline
\end{tabular}

chemistry of the latter type of noritic dykes is not dependent upon crystal accumulation, but also closely resembles the composition of the liquid from which they were derived.

The geochemistry of the noritic dykes does not correspond to that of simple tholeiites, but most closely resembles that of boninites (Kuroda et al., 1978; Cameron et al., 1979; Nelson et $a l ., 1984)$. This geochemical similarity is also reflected by the range of compositions of the magnesian pyroxenes, in particular the elongate $\mathrm{Mg}$-rich pigeonites $\left(\mathrm{Fs}_{15}\right)$ and epitaxially overgrown augite in the partially quenched dyke, the only reported counterparts of which occur in komatiites (Arndt \& Fleet, 1979) (from which the noritic rocks are clearly geochemically distinct) and boninites (Cameron et al., 1979; Wood, 1980). Three samples of the granophyric augite-norite dykes from the eastern Sukkertoppen region have been examined (Table 1, anal. 4) and provide evidence of the extent of chemical evolution of the boniniticnoritic dykes (hereafter referred to as the $\mathrm{BN}$ dykes). These low-MgO (5.7-7.2\%; ionic $\mathrm{Mg}$ / 


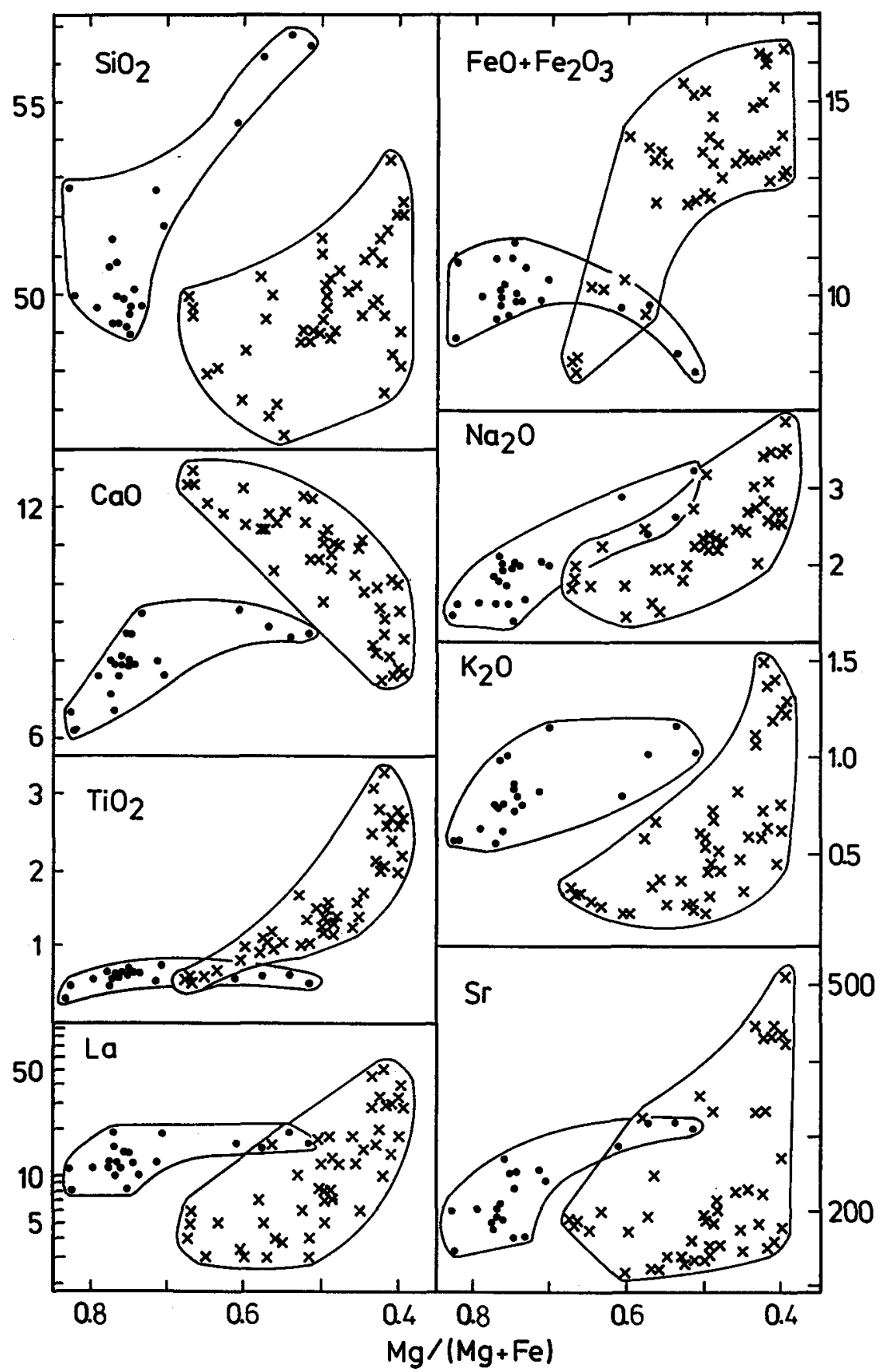

Fig. 4. Abundance of $\mathrm{SiO}_{2},\left(\mathrm{FeO}+\mathrm{Fe}_{2} \mathrm{O}_{3}\right), \mathrm{CaO}, \mathrm{Na}_{2} \mathrm{O}, \mathrm{TiO}_{2}, \mathrm{~K}_{2} \mathrm{O}$, (wt \%) and $\mathrm{La}$ and $\mathrm{Sr}(\mathrm{ppm})$ plotted against ionic $\mathrm{Mg} /(\mathrm{Mg}+\mathrm{Fe})$ for dykes of the boninitic-noritic (BN) suite (dots) and dolerites of the MD dyke swarm (crosses), illustrating the difference in geochemistry of the two suites with respect to these elements. 
$(\mathrm{Mg}+\mathrm{Fe})$ c. 0.6) dykes have high $\mathrm{SiO}_{2}(c .57 \%)$ and alkali contents compared to the other noritic rocks (fig. 4).

Discordant field relationships demonstrate that the norite dykes are older than the MD dolerites and it was thought that they represent the most primitive of the MD dykes (Bridgwater et al., 1976, 1985; Hall et al., 1985). However, it is evident from the geochemical variation diagrams presented in fig. 4 that the $\mathrm{BN}$ dyke swarm is not petrogenetically related to the tholeiitic dolerites of the MD dyke swarm. The two suites are geochemically discrete with respect to several elements (e.g. $\mathrm{Si}, \mathrm{Ca}, \mathrm{Ti}$ and $\mathrm{K}$ ). The only realistic fractionation model which could relate the $\mathrm{BN}$ dykes to the early, most magnesian $\mathrm{MD}$ dolerites $(\mathrm{MgO} c$. $10 \% ; \mathrm{Mg} /(\mathrm{Mg}+\mathrm{Fe})$ c. 0.65$)$ has to involve substantial (c. $25 \%)$ orthopyroxene and lesser olivine removal. Such a model is consistent with the observed mineralogy of the norite dykes and is capable of producing a residual liquid with the $\mathrm{Mg}, \mathrm{Fe}, \mathrm{Al}, \mathrm{Ca}$ and $\mathrm{Si}$ levels encountered in the $\mathrm{MD}$ dolerites. However, this model also increases rather than decreases the levels of $\mathrm{K}, \mathrm{Na}, \mathrm{Rb}, \mathrm{Sr}, \mathrm{Ba}$ and $\mathrm{La}$, which are already higher in the $\mathrm{Mg}$-rich norites than in most of the MD1, MD2 and MD3a dolerites (fig. 4). The BN dykes follow a completely separate evolutionary path for numerous elements. For example, while $\mathrm{MgO}$ decreases significantly (c. $18-6 \%$ ), Fe also decreases slightly and since the alkali contents are relatively higher, the suite does not exhibit the tholeiitic Fe-enrichment trend demonstrated by the MD dolerites (fig. 5a; Hall et al., 1985) but shows affinities with primitive calc-alkaline rocks, as do boninites (Kuroda et al., 1978). Similarly, Ti:Zr ratios also differentiate calc-alkaline and boninitic from tholeiitic suites (Pearce \& Cann, 1973; Nelson et al., 1984). The relative abundances of $\mathrm{Ti}, \mathrm{Zr}$, Sr and $\mathrm{Y}$ correspondingly distinguish the BN from the MD dykes (fig. $5 \mathrm{~b}$, c).

These trends probably also reflect a significant difference in oxygen fugacity $\left(f_{\mathrm{O}_{2}}\right)$ in the two parental magmas. A higher $f_{\mathrm{O}_{2}}$ resulted in the early titano-magnetite and biotite precipitation observed in the noritic dykes, and thus precluded Fe-enrichment in evolving liquids. As a consequence, pyroxene compositions in the norites are relatively uniform. Conversely, the low $f_{\mathrm{O}_{2}}$ of the tholeiitic dolerite magmas restrained magnetite precipitation, causing Fe-enrichment during magma differentiation, and effecting the sequential precipitation of pyroxenes of variable, progressively Fe-rich compositions. The considerable compositional complexity of the pyroxenes in the MD dolerites has already been demonstrated (Hall et al., 1985, 1986).

The petrogenetic separation of the $\mathrm{BN}$ suite from the MD dolerites is further, and perhaps most clearly, demonstrated by the relative abundances of rare-earth elements (REE). The earlier dolerites of the MD swarm have flat chondrite-normalized REE distribution patterns at 10 to 20 times average CI chondrite values (Evensen et al., 1978). The later dolerites have a more evolved, fractionated distribution with light REE over 100 times and heavy REE approximately 20 times chondrite values (Hall et al., 1985). However, the noritic dykes all have markedly fractionated REE distribution patterns (Bridgwater et al., 1985; Hall et al., 1985). New REE data for the boninitic dyke (GGU 290511) and a coarser norite from the same area (GGU 277432) are compared in fig. 6 to those of a granophyric augite-norite dyke (GGU 290506), one of the rare dolerite dykes (GGU 290539) from the same area, and the typical flat distribution of an early (MD2) sample (GGU 149206) from the Fiskenæsset region. Similar fractionated REE distribution patterns have been reported in the 'type B' Cambrian boninites from Victoria, Australia (Nelson et al., 1984) and some of the Tertiary boninites of Cape Vogel and New Caledonia (Cameron et al., 1983). It is not possible to de- 

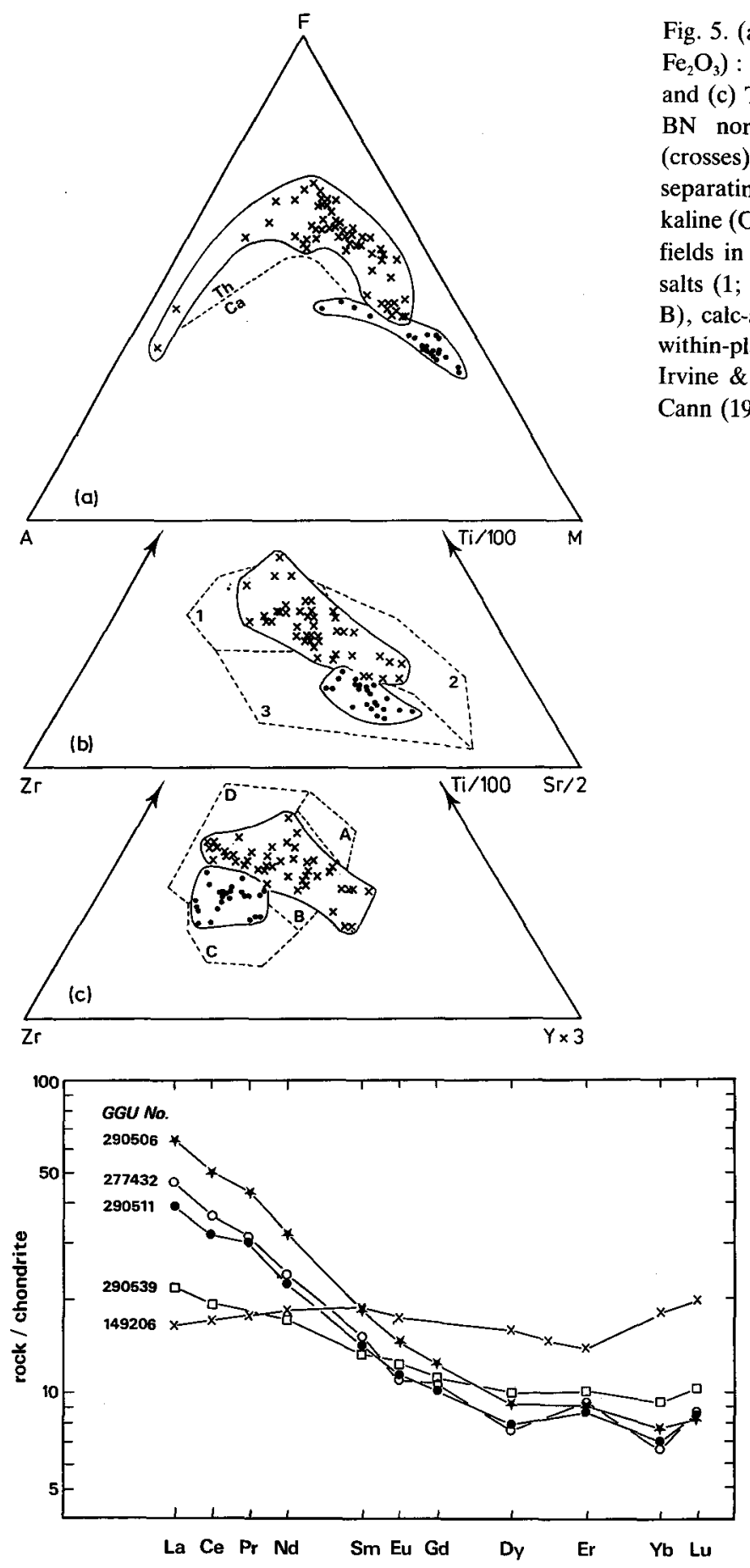

Fig. 5. (a) $\mathrm{A}\left(\mathrm{Na}_{2} \mathrm{O}+\mathrm{K}_{2} \mathrm{O}\right): \mathrm{F}(\mathrm{FeO}+$ $\left.\mathrm{Fe}_{2} \mathrm{O}_{3}\right): \mathrm{M}(\mathrm{MgO})$, (b) Ti/100: $\mathrm{Zr}: \mathrm{Sr} / 2$ and (c) $\mathrm{Ti} / 100: \mathrm{Zr}: \mathrm{Y} \times 3$ plots of the BN norite (dots) and MD dolerite (crosses) dyke swarms. The line in (a) separating the tholeiitic (Th) and calc-alkaline $(\mathrm{Ca}$ ) fields, and the compositional fields in (b) and (c) of ocean-floor basalts $(1 ; B)$, low-K tholeiites $(2 ; A$ and B), calc-alkali basalts (3; B and C) and within-plate basalts (D) are taken from Irvine \& Baragar (1971) and Pearce \& Cann (1973), respectively.
Fig. 6. Chondrite-normalized REE abundances showing the fractionated distribution patterns of the quenched boninitic dyke (GGU 290511), a coarse-grained norite (GGU 277432) and a granophyric augite-norite (GGU 290506) from the eastern Sukkertoppen region, compared to the relatively flat REE patterns of a (rare) dolerite from the same area (GGU 290539) and a typical primitive (MD2) dolerite from the Fiskenæsset region (GGU 149206). 
rive the flat (unfractionated) distribution pattern exhibited by the primitive MD dolerites from a parent which already possesses an evolved, fractionated (norite-type) distribution by any realistic fractional crystallization process. The evolved, granophyric-textured augitenorite which has an even more strongly fractionated (light REE-enriched) distribution clearly demonstrates the effects of fractional crystallization on the REE abundances in the boninitic-noritic suite.

\section{Conclusions}

Early Proterozoic noritic dykes, which are texturally and geochemically distinct from the dolerites of the MD dyke swarm, are abundant in the eastern Sukkertoppen region and occur less commonly throughout the Archaean craton of southern West Greenland (Berthelsen \& Bridgwater, 1960; Hall et al., 1985). The geochemical similarity between the more common, apparently heteradcumulus-textured norites and the quenched boninitic variety in the eastern Sukkertoppen region described in this report, suggests that the geochemistry of the norites has not been significantly influenced by crystal accumulation. These dykes thus form a distinctive boninite-norite suite, the more evolved members of which comprise granophyric-textured augite-norite.

Acknowledgements. The mineral compositions quoted in the paper were determined by us by energydispersive electron microprobe analysis at the Department of Earth Sciences, Cambridge University, and we are grateful to J. V. P. Long for the use of this analytical facility.

\section{References}

Allaart, J. H. A. 1975: (compiler) Geologisk kort over Grønland, 1:500 000. Sheet 1, Sydgrønland. Copenhagen: Grønlands geol. Unders.

Allaart, J. H. A. 1982: (compiler) Geologisk kort over Grønland, 1:500 000. (Sheet 2) Frederikshåbs Isblink-Søndre Strømfjord. Copenhagen: Grønlands geol. Unders.

Andrews, J. R. 1973: Stratigraphic, structural and metamorphic features of Archaean (pre-Ketilidian) rocks in the Frederikshåbs district, South-West Greenland. In Park, R. G. \& Tarney, J. (edit.) The early Precambrian rocks of Scotland and related rocks of Greenland, 179-187. Univ. Keele.

Arndt, N. T. \& Fleet, M. E. 1970: Stable and metastable pyroxene crystallization in layered komatiite lava flows. Amer. Mineral. 64, 856-864.

Berthelsen, A. \& Bridgwater, D. 1960: On the field occurrence and petrography of some basic dykes of supposed Pre-Cambrian age from the southern Sukkertoppen district, western Greenland. Bull. Grønlands geol. Unders. 24 (also Meddr Grønland 123(3)), 43 pp.

Bridgwater, D., Keto, L., McGregor, V. R. \& Myers, J. S. 1976: Archaean gneiss complex of Greenland. In Escher, A. \& Watt, W. S. (edit.) Geology of Greenland, 18-75. Copenhagen: Geol. Surv. Greenland.

Bridgwater, D., Fryer, B. J. \& Gorman, B. E. 1985: Proterozoic basic dykes in southern Greenland and the coast of Labrador; tectonic setting, intrusion forms and chemistry. In: Int. Conf. Mafic Dyke Swarms, Toronto (1985), Abs. 15-21. Univ. Toronto.

Cameron, W. E., Nisbet, E. G. \& Dietrich, V. J. 1979: Boninites, komatiites and ophiolitic basalts. Nature 280, 550-553.

Cameron, W. E., McCulloch, M. T. \& Walker, D. A. 1983: Boninite petrogenesis: chemical and Nd-Sr isotopic constraints. Earth planet. Sci. Lett. 65, 75-89. 
Evensen, N. M., Hamilton, P. J. \& O'Nions, R. K. 1978: Rare-earth abundances in chondritic meteorites. Geochim. cosmochim. Acta 42, 1199-1212.

Garde, A. A., Hall, R. P., Hughes, D. J., Jensen, S. B., Nutman, A. \& Stecher, O. 1983: Mapping of the Isukasia sheet, southern West Greenland. Rapp. Grønlands geol. Unders. 115, 20-29.

Hall, R. P. 1977: The Precambrian geology of the Kangangûp tasia area, Fiskenæsset, southern West Greenland. Unpublished M.Phil. thesis, Council for National Academic Awards.

Hall, R. P. 1981: The Archaean geology of Ivisârtoq, inner Godthåbsfjord, southern West Greenland. Unpublished Ph.D. thesis, Council for National Academic Awards.

Hall, R. P., Hughes, D. J. \& Friend, C. R. L. 1985: Geochemical evolution and unusual pyroxene chemistry of the MD tholeiite dyke swarm from the Archaean craton of southern West Greenland. $J$. Petrol. 26(2), 253-282.

Hall, R. P., Hughes, D. J. \& Friend, C. R. L. 1986: Complex sequential pyroxene growth in tholeiitic hypabyssal rocks from southern West Greenland. Mineralog. Mag. 50 (in press).

Irvine, T. N. \& Baragar, W. R. A. 1971: A guide to the chemical classification of common volcanic rocks. Can. J. Earth Sci. 8, 523-548.

Kalsbeek, F. \& Taylor, P. N. 1985: Age and origin of early Proterozoic dolerite dykes in South-West Greenland. Contr. Mineral. Petrol. 89, 307-316.

Kuroda, N., Shiraki, K. \& Urano, H. 1978: Boninite as a possible calc-alkaline primary magma. Bull. Volcanol. 41, 563-575.

Nelson, D. R., Crawford, A. J. \& McCulloch, M. T. 1984: Nd-Sr isotopic and geochemical systematics in Cambrian boninites and tholeiites from Victoria, Australia. Contr. Mineral. Petrol. 88, 164-172.

Pearce, J. A. \& Cann, J. R. 1973: Tectonic setting of basic volcanic rocks determined using trace element analyses. Earth planet. Sci. Lett. 19, 290-300.

Rivalenti, G. 1975: Chemistry and differentiation of mafic dykes in an area near Fiskenæsset, West Greenland. Can. J. Earth Sci. 12, 721-730.

Wood, C. P. 1980: Boninite at a continental margin. Nature 288, 692-694.

Department of Geology, Portsmouth Polytechnic, Burnaby Road, Portsmouth PO1 $3 Q L$, U.K.

\title{
On the occurrence of scheelite in the Archaean Malene supracrustal rocks, southern West Greenland
}

\author{
Peter W. Uitterdijk Appel and Adam A. Garde
}

Scheelite in the Godthåbsfjord area (fig. 1) was found in heavy mineral concentrates from stream sediments in 1982, and in situ scheelite was discovered in 1982 on Stor $\emptyset$ in Godthåbsfjord (Appel, 1983a). During 1983 further work was carried out on the islands of Storø and Sermitsiaq in Godthåbsfjord and on the Store Malene mountain next to Nuuk (Godthåb), as a result of which several scheelite-bearing horizons were found (Appel, 1984). During 1985 a detailed mapping programme was carried out on Store Malene by $A$. A. Garde. Subsequently, exposures on Store Malene as well as the island of Simiútat south 